\title{
Design and Estimation of Reinforced Building: A Case Study
}

\author{
Akshay Chaudhary ${ }^{1}$, Payal Sachdeva ${ }^{2}$, Maninderpal Singh ${ }^{3}$ \\ ${ }^{1,2}$ (Assistant Professor, Department of Civil Engineering, CGC Technical Campus, Jhanjeri, Mohali, India) \\ ${ }^{3}$ (Department of Civil Engineering, CGC Technical Campus, Jhanjeri, Mohali, India) \\ ( ${ }^{1}$ akki016@gmail.com, ${ }^{2}$ payalsachdeva140@gmail.com, ${ }^{3}$ maninder.singh149@gmail.com)
}

\begin{abstract}
For estimating the cost of the structure, it is necessary for the quantities of the materials, including those of the reinforcement to be known. Accurate quantities of the concrete and brickwork can be calculated from the layout drawings. If working drawings and schedules for the reinforcement are not available it is necessary to provide an estimate of the anticipated quantities. The quantities are normally described in accordance with the requirements of the Standard method of measurement of building works. There are different methods for estimating the quantities of reinforcement. The first method is based on the type of structure and the volume of the reinforced concrete elements. The second method, uses factors that convert the steel areas obtained from the initial design calculations to weights, e.g. $\mathrm{kg} / \mathrm{m}^{2}$ or $\mathrm{kg} / \mathrm{m}$ as appropriate to the element. This method is likely to be the most flexible and relatively precise in practice, as it is based on reinforcement requirements indicated by the initial design calculations. Third method is the one in which sketches are made for the 'typical' cases of elements and then weighted.

In this paper, the cost of the various structures of the Administrative block of the building are carried out. Design part is carried by the use of IS Code 456:2000. All the details regarding the design is presented in the report. Additionally, figures displaying the various detailing regarding the beam, lintel, staircase design etc and placement of the steel rebar in the structure are contained in the report. The structural system cost and the cost premium for seismic safety are presented. The results of the study would be useful for design professionals and quantity surveyors.
\end{abstract}

Keywords - Building, Cost, Design, Estimation and Seismic Safety.

\section{INTRODUCTION}

The aim of design is the achievement of an acceptable probability that structures being designed will perform satisfactorily during their intended life. With an appropriate degree of safety, they should sustain all the loads and deformations of normal construction and use and have adequate durability and adequate resistance to the effects of misuse and fire.

Structure and structural elements shall normally be designed by Limit State Method. Account should

Be taken of accepted theories, experiment and experience and the need to design for durability. Calculations alone do not produce safe, serviceable and durable structures. Suitable materials, quality control. Adequate detailing and good supervision are equally important. Where the Limit State Method cannot be conveniently adopted, Working Stress Method may be used.

Designs based on experimental investigations on models or full size structure or element may be accepted if they satisfy the primary requirements as mentioned in the first paragraph and subject to experimental details and the analysis connected therewith being approved by the engineer-in-charge [1].

For estimating the cost of the structure, it is necessary for the quantities of the materials, including those of the reinforcement to be known. Accurate quantities of the concrete and brickwork can be calculated from the layout drawings. If working drawings and schedules for the reinforcement are not available it is necessary to provide an estimate of the anticipated quantities. The quantities are normally described in accordance with the requirements of the Standard method of measurement of building works.

There are different methods for estimating the quantities of reinforcement; three methods of varying accuracy are:

(A)The simplest method is based on the type of structure and the volume of the reinforced concrete elements. 
(B)Another method is to use factors that convert the steel areas obtained from the initial design calculations to weights, e.g. $\mathrm{kg} / \mathrm{M}^{2}$ or $\mathrm{kg} / \mathrm{m}$ as appropriate to the element. This method is likely to be the most flexible and relatively precise in practice, as it is based on reinforcement requirements indicated by the initial design calculations.

(C)Third method is the one in which sketches are made for the 'typical' cases of elements and then weighted [4].

Cost estimation in construction projects is an important factor for decision making in both the early phase and the detailed design phase. The construction phase based on Quantity take off [QTO] can function for procurement and predicting construction costs [2]. In addition, 2D-based estimation lacks uncertainty factors for estimation [3]. Accordingly, construction project seek more accurate QTO and cost estimation. Reliable estimates require accurate building information. Inaccurate information from QTO produces estimation errors because schematic estimation in the early phase process is multiplied by unit cost.

In this paper, the cost of the various structures of the Administrative block of the building are carried out. Design part is carried by the use of IS Code 456:2000. All the details regarding the design is presented in the report. Additionally, figures displaying the various detailing regarding the beam, lintel, staircase design etc and placement of the steel rebar in the structure are contained in the report. The structural system cost and the cost premium for seismic safety are presented. The results of the study would be useful for design professionals and quantity surveyors [5].

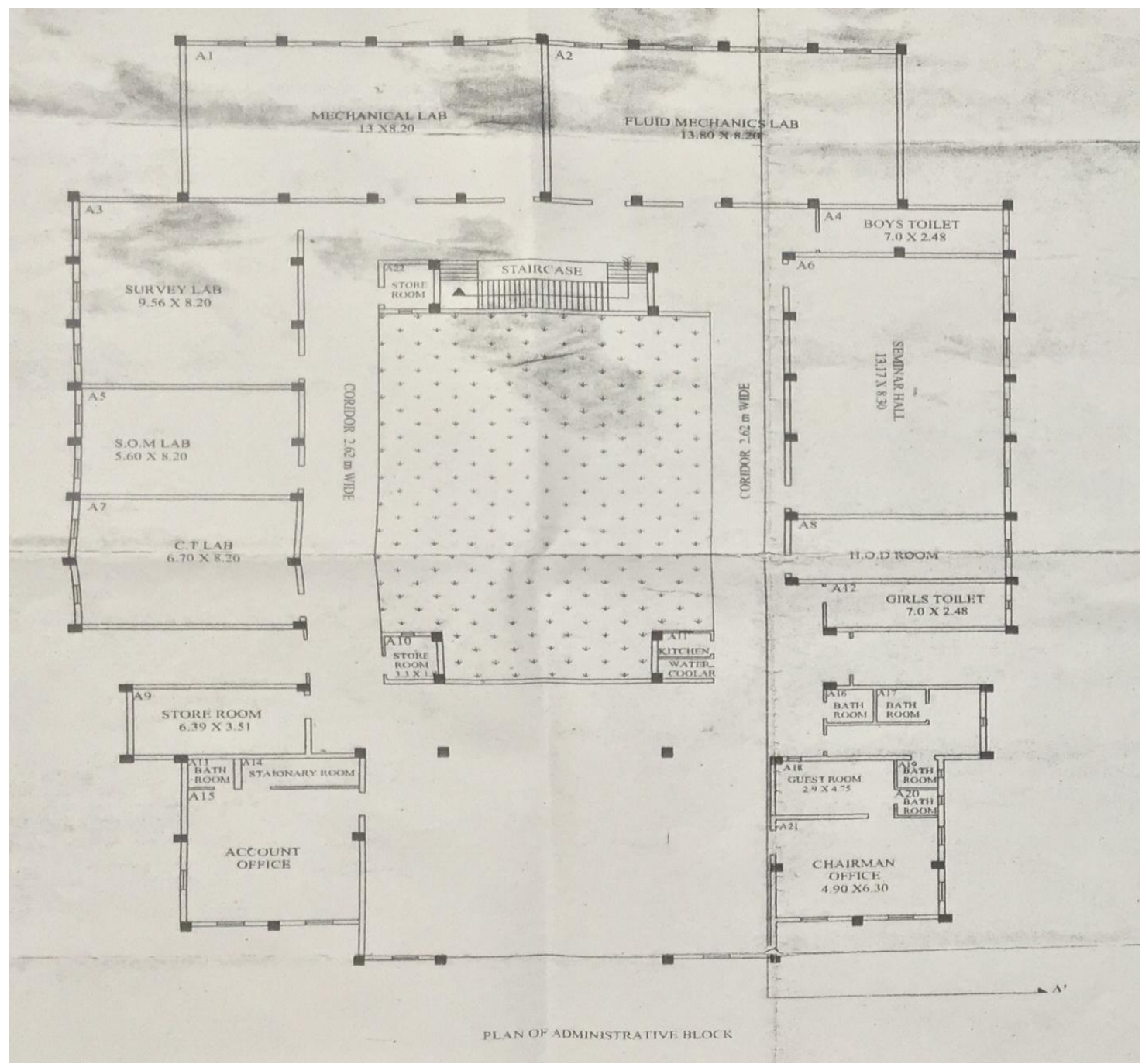

Figure 1: Plan of Administrative Block 


\section{DESIGN}

The summary of design of the reinforced concrete structure entailed a number of steps and calculations. Each section listed below describes the results obtained in the process of the design [1] [6].

A) Design of Slab - For the designing of slab, required formulae for the design part were taken from IS CODE 456:2000. The results obtained were:

Overall thickness of the Slab $=200 \mathrm{~mm}$

Effective thickness of Slab $=170 \mathrm{~mm}$

Reinforcement along short span=12 mm dia, bars @ 200mm C/C

Reinforcement along long span $=12 \mathrm{~mm} \mathrm{dia}$, bars @ $150 \mathrm{~mm} \mathrm{C/C}$
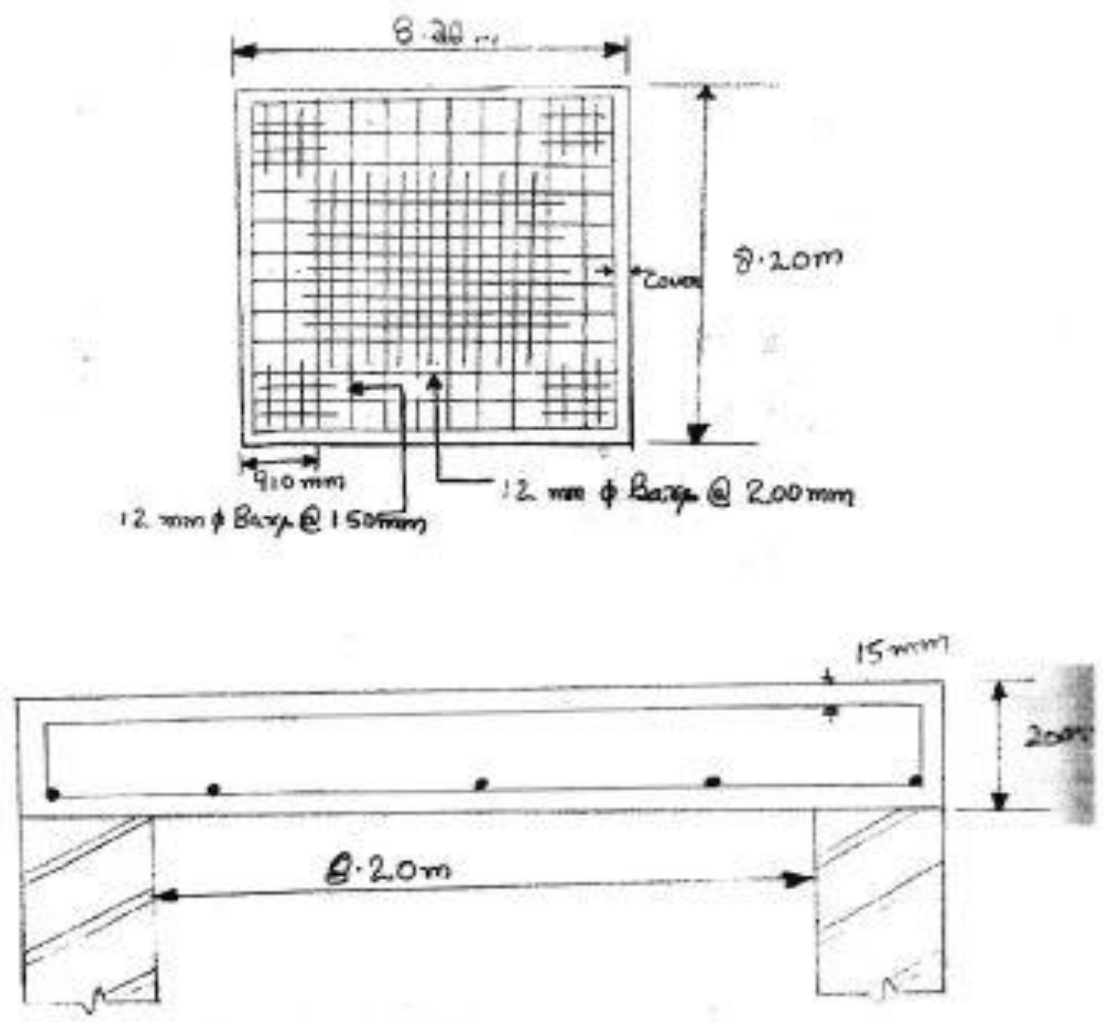

\section{REINFORCEMENT R.C.C. SLAB DRAWING DETAILING OF SLAB}

Fig 2: Reinforcement Detailing of Slab

B) Design of Beam - For the designing of beam, required formulae for the design part were taken from IS CODE 456:2000. The results were obtained based upon $S p a n=8.2 \mathrm{~m}, \mathrm{~B}=400 \mathrm{~mm}, \mathrm{D}=500 \mathrm{~mm}$, $\mathrm{M} 20$ \& $\mathrm{Fe} 415$

Spacing between bars: (i) Tension spacing $55 \mathrm{~mm}=5$ bars of $16 \mathrm{~mm}$ dia.

(ii) Compression zone spacing is $60 \mathrm{~mm}=5$ bars of $12 \mathrm{~mm}$ dia. 

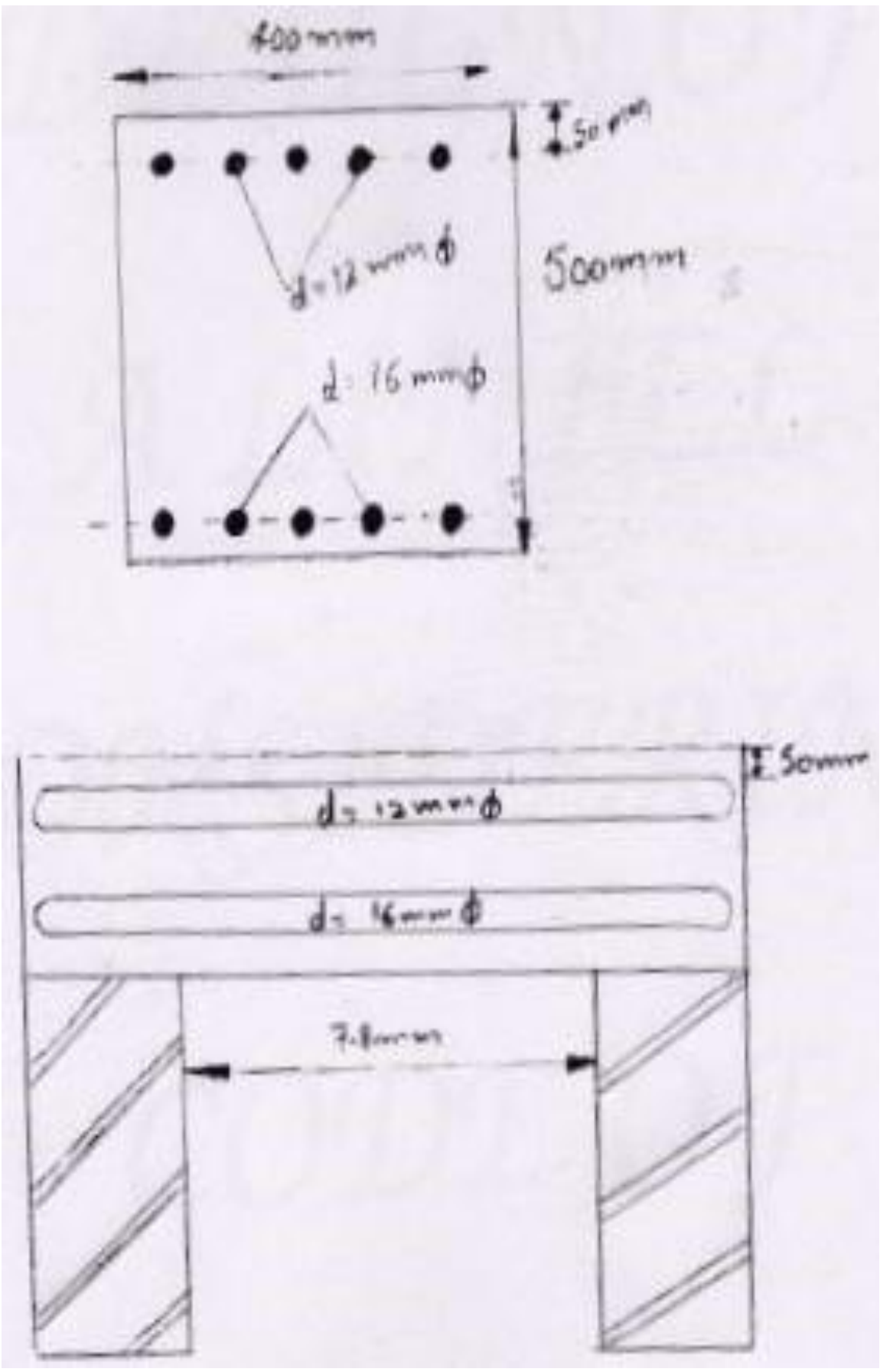

Fig 3: Reinforcement detailing of Beam

C) Design of Lintel - For the designing of lintel, required formulae for the design part were taken from IS CODE 456:2000. The results obtained were:

Size of Lintel $-200 \mathrm{~mm} * 230 \mathrm{~mm}$

Main Steel $=2$ bars of $10 \mathrm{~mm}$ dia.

Anchor bars $=2$ bars of $10 \mathrm{~mm}$ dia.

Stirrups = $6 \mathrm{~mm}$ dia. 2 legged @ $130 \mathrm{~mm} \mathrm{c/c}$ 


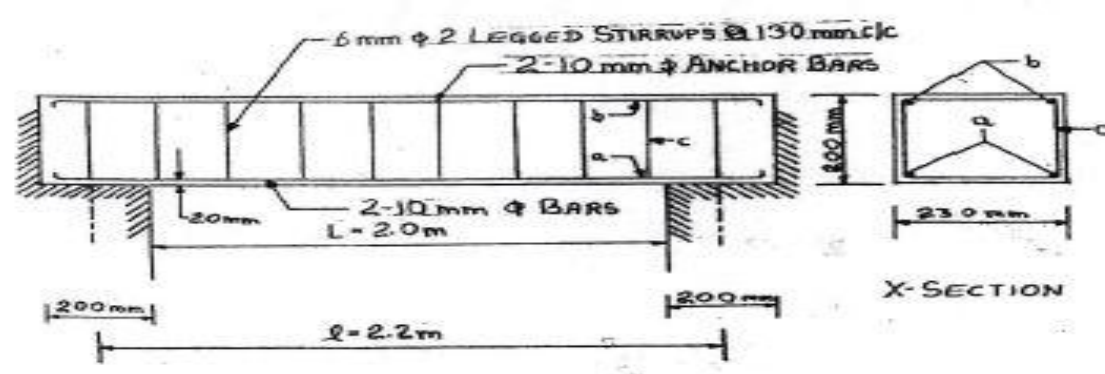

L-SECTION

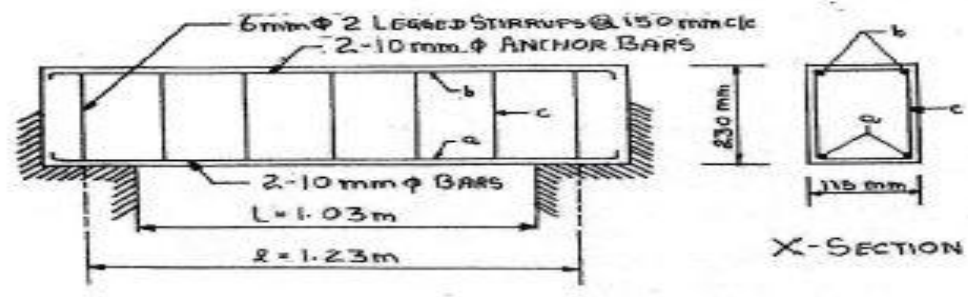

L-SECTMON

\section{REINFORCEMENT DETAILS OF LINTELS}

Figure 4: Reinforcement Detailing of Lintel

D) Design of Staircase - For the designing of Staircase, required formulae for the design part were taken from IS CODE 456:2000. The results obtained are shown in the figure5.
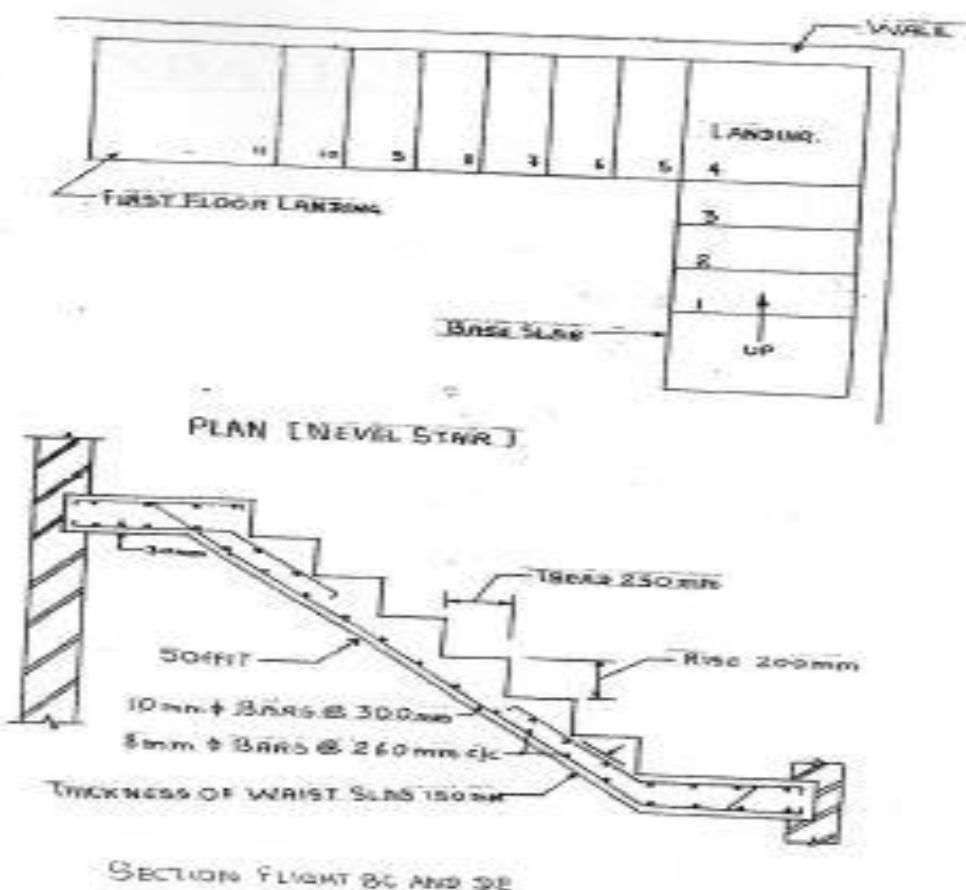

Fig 5: Section Flight 
E) Design of Column - For the designing of Column, required formulae for the design part were taken from IS CODE 456:2000. The results obtained are shown in the figure 6.

$\mathrm{B}=400 \mathrm{~mm}, \mathrm{D}=500 \mathrm{~mm}$, Length $=3500 \mathrm{~mm}$

Live load $=56.4 \mathrm{KN} / \mathrm{m}$, Dead Load $=5 \mathrm{KN} / \mathrm{m}$ and Factored load $=92.1 \mathrm{KN} / \mathrm{m}$

Gross area of concrete provided $=2000 \mathrm{sq} \mathrm{cm}$

Longitudinal area of steel $=1600 \mathrm{sq} \mathrm{mm}$

Use 6 bars of $18 \mathrm{~mm}$ dia. Giving total area $=1526.02 \mathrm{sq} . \mathrm{mm}$

Diameter \& Pitch of lateral ties $=4.5 \mathrm{~mm}$ dia. $\&$ pitch of $300 \mathrm{~mm} \mathrm{c} / \mathrm{c}$ is adopted
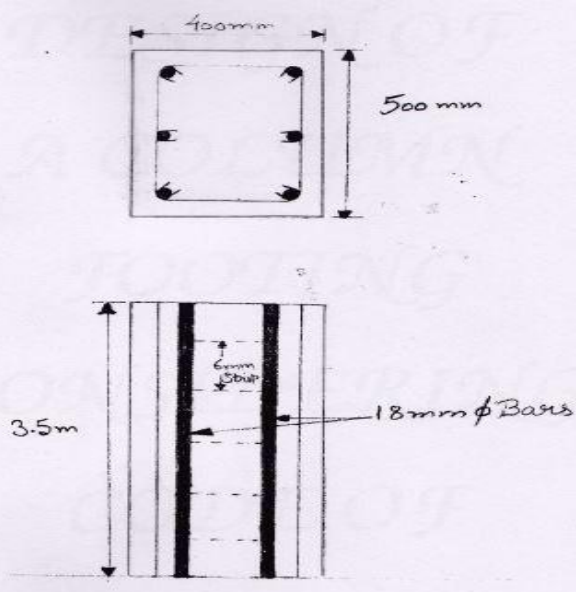

DESIGN OF COLUMN

Figure 6: Design of Column

F) Design of Column Footing - For the designing of Column footing, required formulae for the design part were taken from IS CODE 456:2000. The results obtained are shown in the figure 7.

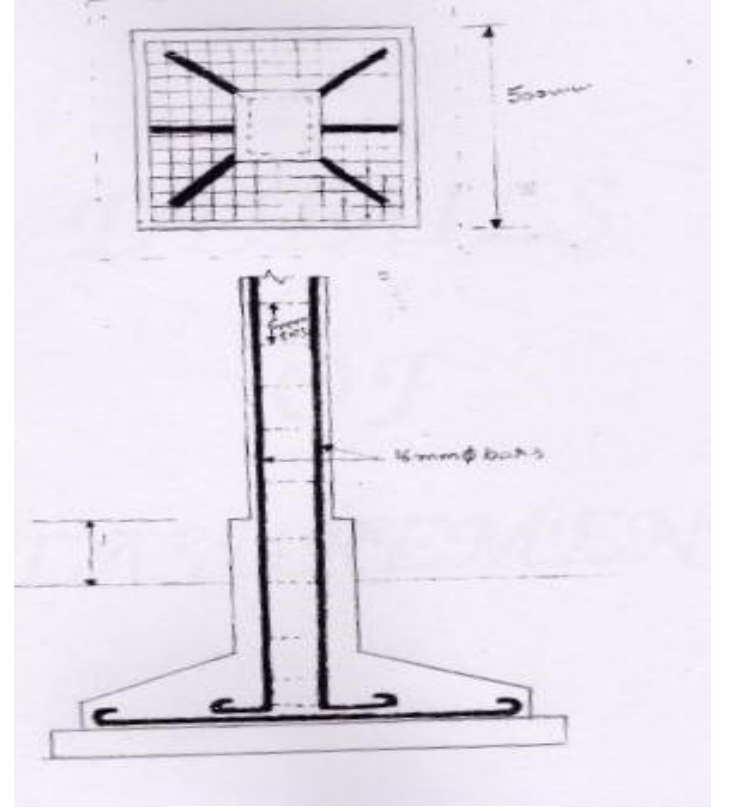

Figure 7: Design of Column 
IOSR Journal of Mechanical and Civil Engineering (IOSR-JMCE)

e-ISSN: 2278-1684, p-ISSN: 2320-334X

\section{ABSTRACT OF COST}

Table I. Cost Calculation of Various Components of Building

\begin{tabular}{|c|c|c|c|c|c|}
\hline \multirow{2}{*}{$\begin{array}{l}\text { Particulars } \\
\text { SUB-HEAD } \\
\text { 1 EARTHWORK }\end{array}$} & \multirow[t]{2}{*}{ Qty. } & \multicolumn{2}{|c|}{ Units of payment } & \multirow{2}{*}{$\begin{array}{c}\text { Rate (Rs.) } \\
\text { PREMIUM }\end{array}$} & \multirow[t]{2}{*}{ Amount (Rs.) } \\
\hline & & & & & \\
\hline Excavation for Foundation & 187.332 & $\%$ cu.m & 1108.10 & $350 \%$ & 934121.65 \\
\hline Earth Filling under Floor & 379.89 & $\%$ cu.m & 343.40 & $300 \%$ & 521816.90 \\
\hline \multicolumn{6}{|l|}{$\begin{array}{l}\text { SUB-HEAD } \\
\text { II CONCRETE }\end{array}$} \\
\hline Base Concrete 1:5:10 & 62.44 & $\begin{array}{l}\text { Per } \\
\text { cu.m }\end{array}$ & 354.05 & $370 \%$ & 103893.54 \\
\hline \multicolumn{6}{|l|}{ Damp proof Course } \\
\hline $\begin{array}{l}\text { H.D.P.C } 4 \mathrm{~cm} \text { Thick } 1: 2: 4 \text { with the two coats } \\
\text { of bitumen laid hot }\end{array}$ & 106.11 & $\begin{array}{c}\text { Per } \\
\text { sq.m }\end{array}$ & 33.05 & $340 \%$ & 16364.28 \\
\hline \multicolumn{6}{|l|}{$\begin{array}{l}\text { SUB-HEAD } \\
\text { III Brickwork }\end{array}$} \\
\hline $\begin{array}{l}1^{\text {st }} \text { Class brickwork in cement mortar 1:6 in } \\
\text { foundation and plinth }\end{array}$ & 73.32 & $\begin{array}{l}\text { Per } \\
\text { cu.m }\end{array}$ & 393.45 & $400 \%$ & 144238.77 \\
\hline $\begin{array}{l}1^{\text {st }} \text { Class brickwork in cement mortar 1:6 in } \\
\text { super structure }\end{array}$ & 213.61 & $\begin{array}{l}\text { Per } \\
\text { cu.m }\end{array}$ & 414.45 & $400 \%$ & 442653.32 \\
\hline \multicolumn{6}{|l|}{$\begin{array}{l}\text { SUB-HEAD } \\
\text { V Flooring Work }\end{array}$} \\
\hline Tiles Flooring & 1233.66 & $\begin{array}{c}\text { Per } \\
\text { sq.m }\end{array}$ & 251.35 & $120 \%$ & 682176.97 \\
\hline \multicolumn{6}{|l|}{$\begin{array}{l}\text { SUB-HEAD } \\
\text { VI Finishing }\end{array}$} \\
\hline $\begin{array}{l}\text { Cement Plaster 1:4 (10mm thick) under } \\
\text { ceiling }\end{array}$ & 1233.66 & $\begin{array}{c}\text { Per } \\
\text { sq.m }\end{array}$ & 12.65 & $340 \%$ & 65665.51 \\
\hline $\begin{array}{l}\text { Cement Plaster 1:5 (12mm Thick) on inner } \\
\text { walls }\end{array}$ & 584.4 & $\begin{array}{l}\text { Per } \\
\text { sq.m }\end{array}$ & 11.60 & $340 \%$ & 29827.77 \\
\hline $\begin{array}{l}\text { Cement Plaster 1:5 (12mm Thick) on outer } \\
\text { walls }\end{array}$ & 2267.74 & $\begin{array}{l}\text { Per } \\
\text { sq.m }\end{array}$ & 14.25 & $340 \%$ & 142187.29 \\
\hline \multicolumn{6}{|l|}{$\begin{array}{l}\text { SUB-HEAD } \\
\text { VII Wood Work }\end{array}$} \\
\hline Shutters & 483.97 & $\begin{array}{l}\text { Per } \\
\text { sq.m }\end{array}$ & 404.90 & $250 \%$ & 685858.08 \\
\hline \multicolumn{6}{|l|}{$\begin{array}{l}\text { SUB-HEAD } \\
\text { VIII Painting }\end{array}$} \\
\hline Two Coat white wash & 4085.80 & $\begin{array}{c}\text { Per } \\
\text { sq.m }\end{array}$ & 0.90 & $140 \%$ & 8825.32 \\
\hline \multicolumn{6}{|l|}{$\begin{array}{l}\text { SUB-HEAD } \\
\text { IX Steel }\end{array}$} \\
\hline $\begin{array}{l}\text { Steel Reinforcement bars including bending } \\
\text { in RCC Work }\end{array}$ & 816.61 & $\begin{array}{c}\text { Per } \\
\text { Quintel }\end{array}$ & 917.05 & $450 \%$ & 4118662.36 \\
\hline TOTAL & & & & & 7899291.76 \\
\hline $\begin{array}{l}\text { Add } 13 \% \text { water supply and sanitary } \\
\text { installation }\end{array}$ & & & & & 1026907.93 \\
\hline Add $13 \%$ electricity installation & & & & & 1026907.93 \\
\hline Add 5\% architectural design and drawing & & & & & 394964.58 \\
\hline & $\begin{array}{l}\text { OVERA } \\
\text { LL }\end{array}$ & & & & 10348072.18 \\
\hline
\end{tabular}




\begin{tabular}{|l|l|l|l|l|l|}
\hline & TOTAL & & & & \\
\hline Add Contingencies 5\% Overall & & & & & 517403.60 \\
\hline & $\begin{array}{c}\text { GRAND } \\
\text { TOTAL }\end{array}$ & & & & $\mathbf{1 0 8 6 5 4 7 5 . 7 8}$ \\
\hline
\end{tabular}

\section{CONCLUSION}

It is possible to improve the seismic resistance of a building by following the simple planning principal as discussed here after:

1. The plane shape should be kept simple, the length to width ratio should not exceed. The building structure should be as symmetrical as possible along each principal axis.

2. If recess is required, they should not exceed $25 \%$ of overall dimensions in the corresponding direction.

3. The elevation should be regular; top heavy facades where mass is concentrated at upper storage should be avoided.

4. Walls are to be uniformly distributed. The total cross-sectional area of structural walls should be $3 \%$ of gross area. The minimum thickness of load bearing walls equals to length of one brick. Partition walls should be reinforced with 3 no's of $6 \mathrm{~mm}$ diameter in every fourth layer.

5. Openings should possible be located in walls. The tops of the openings in the storey should be at the same horizontal level. Lintels on openings should have a maximum and minimum bearing of $250 \mathrm{~mm}$ at both ends to prevent local collapse. Width of lintel should not be less than $150 \mathrm{~mm}$.

\section{REFERENCES}

[1] IS 456:2000: Code of practice for plain and reinforced concrete (fourth revision).

[2] A. Tuan, J.Y. Park, Development of integrated design methodology for various types of product - service systems, Journal of Computational Design and Engineering, 1 (1) (2014), pp. 37-47

[3] Choi CH, Park YJ, Han SH, Chin SY. Recipe-based estimation system for 5D (3D+Cost+Schedule) CAD system. In: Academic Conference of Korean Construction Management Association; 2006; p. 154-160.

[4] ATC: Tentative provisions for the development of seismic regulations for buildings, Report N. ATC3-06, Applied Technology Council, California, 1978 .

[5] A. Bartolini, Reinforced Concrete Design Project Five Storey Office Building (December, 2007)

[6] Manual for the design of reinforced concrete building structures to EC2 (March 2000). 